\title{
INJURIES TO THE PRIMARY TEETH AND SOFT TISSUES IN CHILDREN IN NIŠ, SERBIA
}

\author{
Ana Igić1, Branislava Stojković2,3, Aleksandar Mitić2,4, Aleksandar Acović5, \\ Kosta Todorović2,6, Ana Todorović2,7, Dušan Sokolović2,8, Marija Igić ${ }^{2}$
}

\begin{abstract}
The aim of this study was to analyze injuries to the primary teeth and adjacent soft tissues in relation to the gender and age of injured children, type of injury, place, and mechanism of injury. The study enrolled 115 children (71 boys and 44 girls) managed at the Dentistry Clinic, Faculty of Medicine, University of Niš, in the period 2009-2019. The information about the type of injury, place, and mechanism of injury were obtained from the medical records of the patients aged 1-5 years. Our analysis established that there were statistically significantly $(p<0.05)$ more injured boys $(61.74 \%)$ than girls $(38.26 \%)$. Subluxation was the most common primary teeth injury, present in $60(52.17 \%)$ children and was statistically significantly more prevalent compared to other injuries $(p<0.001)$. Of the injuries to the adjacent soft tissues, laceration was statistically significantly more common than other soft tissue injuries $(p<0.001)$. Children were most commonly injured at their homes $(52.17 \%)$, and rarely in their day nurseries (3.48\%). Falling was the most common cause of injuries $(63.48 \%)$. Based on the obtained results, a conclusion may be drawn that boys were more commonly injured compared to girls, and that falls were the most common cause. Injuries usually occurred at the age of about 2 years. Subluxation was the most common injury, and children usually got injured at their own home.
\end{abstract}

Acta Medica Medianae 2021;60(1):56-62.

Key words: primary teeth, injuries, subluxation, laceration

\footnotetext{
${ }^{1}$ University of Niš University of Niš, Faculty of Medicine, PhD student, Niš, Serbia

${ }^{2}$ University of Niš, Faculty of Medicine, Niš, Serbia

${ }^{3}$ Clinic of Dentistry, Department of Preventive and Paediatric Dentistry, Niš, Serbia

${ }^{4}$ Clinic of Dentistry, Department of Endodontics, Niš, Serbia

${ }^{5}$ University of Kragujevac, Faculty of Medical Sciences,

Department of Dentistry, Kragujevac, Serbia

${ }^{6}$ Clinic of Dentistry, Department of Oral Surgery, Niš, Serbia

${ }^{7}$ Clinic of Dentistry, Department of Orthodontics, Niš, Serbia

${ }^{8}$ University of Nišs, Faculty of Medicine, Department of

Biochemistry, Niš, Serbia
}

Contact: Ana Igić

81 Dr Zoran Djindjić Blvd., 18000 Niš, Serbia

E-mail: igic.ana77@gmail.com

\section{Introduction}

The modern way of life has been increasingly exposing children to various injuries, so that injuries to the teeth and adjacent soft tissues are becoming more and more common. Any damage to the structure of dental tissues and their supporting 56 apparatus, in any degree, disturbs the function of mastication, cosmesis, and produces speech difficulties, which stresses the significance of the problem. Injuries to the primary teeth usually occur between the $3^{\text {rd }}$ and $4^{\text {th }}$ year of life (1-4). In that period of their development, children have a strong urge to explore their immediate environment, and because of their insufficiently developed motoric skills, inability to properly assess imminent dangerous situations, lack of control of the impulses, and unawareness of the consequences of their actions, they are more susceptible to various injuries. The causes of dental injuries at that age are diverse, and the most common are falls while running or playing, as well as collisions with various objects. In addition to teeth, soft tissues of the orofacial region may be injured as well.

Due to great elasticity of the bone and weakness of the periodontal ligament, injuries to periodontal tissues are much more common with primary teeth compared to permanent ones $(3,5)$. Avulsions of the primary teeth in children aged under 2 years are especially common - in that period the growth of the dental roots is not yet completed.

Since in pediatric populations traumas are mostly the consequence of falls or these are injuries acquired while playing, it is very difficult to prevent them. It is not at all uncommon that injuries to the 
teeth are the reason for the child's first visit to the dentist (6). Injuries to the teeth and adjacent soft tissues are not only a physical and psychological trauma for the child, but for the parents as well. An adequate approach and treatment by the dentist is essential in such situations.

\section{The aim}

Our aim in the paper was to analyze injuries to the primary teeth and adjacent soft tissues in relation to the gender and age, type, place, and mechanism of injury.

\section{Materials and methods}

The information about the type, place, and mechanism of injury were obtained from the medical records of patients aged 1-5 years, therapeutically managed at the Dental Clinic in Niš in the period 2009-2019. The study involved 115 children (71 boys and 44 girls). We analyzed the type of tooth injury, gender and age distribution, as well as the cause and place where the injury oocurred. Tooth injuries were classified according to the Andreasen and Andreasen classification (7), while injuries to the adjacent soft tissues were categorized as lacerations, contusions, abrasions and swellings.

The obtained data were statistically processed (Chi square test) and presented in tables.

The study was conducted according to the World Medical Association's Declaration of Helsinki and approved by the Ethical Committee of the Faculty of Medicine, University of Niš.

\section{Results}

The study enrolled 115 children with diagnosed injuries to the primary teeth and adjacent soft tissues. The number of male children ( $\mathrm{n}=71$; $61.74 \%$ ) was statistically significantly higher than that of female children $(n=44 ; 38.26 \%)(p<0.05)$ (Graph 1).

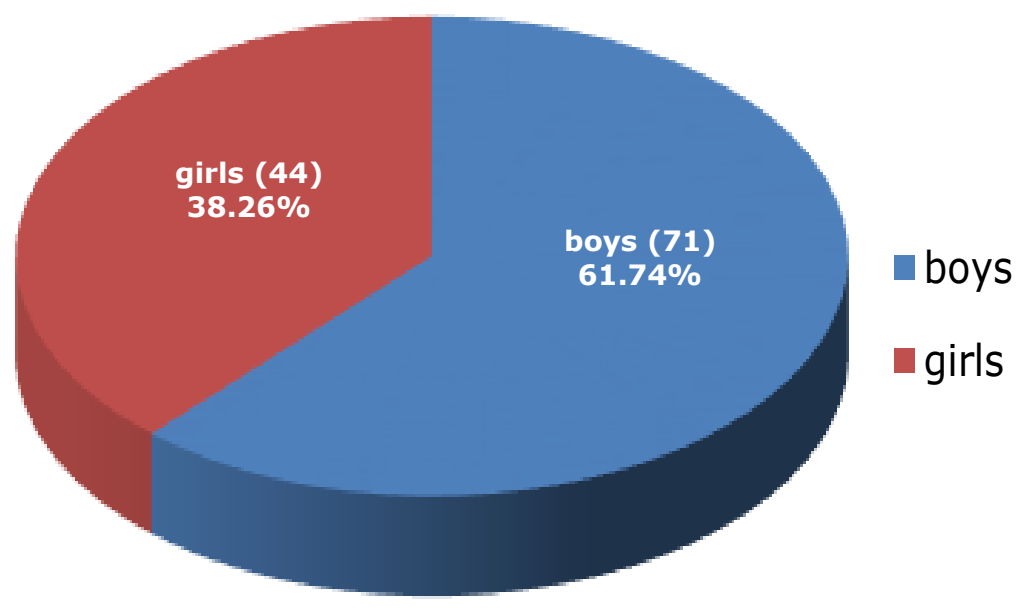

Graph 1. Prevalence of injuries by gender

The sample was inhomogenous related to the place of occurrence of tooth injuries ( $p<0.001$ ). Children most commonly got injured at their homes (60 examinees; 52.17\%), and injuries in children day care institutions (kindergartens) were the rarest (4 examinees; $3.48 \%$ ). As the place where children got injured, home was statistically more common compared to all other places individually ( $p<0.001)$. Girls statistically significantly more commonly got injured in the street than boys $(p<0.05)$ (Table 1$)$.

The sample was not uniform as to the mechanism of injury either $(p<0.001)$. Children most commonly got injured by falling (73 examinees; $63.48 \%)$, which was statistically significantly more common compared to injuries inflicted by punching and bicycle injuries each $(p<0.001)$ (Table 2$)$.

The most common periodontal soft tissue injury was laceration (31 children; 26.96\%), being statistically significantly more common than abrasions or swellings each $(p<0.001)$. Lacerations were most common in boys, and contusion was per a single examinee more common compared to laceration in girls. Contusions were statistically significantly more common in girls than in boys ( $p<$ 0.05) (Table 3).

The most common injury to the primary teeth was subluxation (60 children; $52.17 \%$ ), being more common than any other reported injury ( $p<0.001)$ (Table 4). 
Since the prevalence of fractures was relatively low, their prevalence by the factor of class was low too. There were no statistically significant differences in the prevalence of fracture classes between the studied groups (Table 5).

Table 1. Place of injury

\begin{tabular}{|c|c|c|c|c|c|c|}
\hline Place of injury & \multicolumn{2}{|c|}{ Male gender } & \multicolumn{2}{|c|}{ Female gender } & \multicolumn{2}{|c|}{ Total } \\
\hline Home & 39 & $54.93 \%$ & 21 & $47.73 \%$ & 60 & $52.17 \%$ \\
\hline Backyard & 17 & $23.94 \%$ & 6 & $13.64 \%$ & 23 & $20.00 \%$ \\
\hline Park & 7 & $9.86 \%$ & 7 & $15.91 \%$ & 14 & $12.17 \%$ \\
\hline Street & 5 & $7.04 \%$ & 9 & $20.45 \%$ * & 14 & $12.17 \%$ \\
\hline Day care (kindergarten) & 3 & $4.23 \%$ & 1 & $2.27 \%$ & 4 & $3.48 \%$ \\
\hline Total & 71 & $100.00 \%$ & 44 & $100.00 \%$ & 115 & $100.00 \%$ \\
\hline
\end{tabular}

$* p<0.05$

Table 2. Mechanism of injury

\begin{tabular}{||l||c|c|c|c|c|c||}
\hline \hline \multicolumn{1}{||||}{ Mechanism of injury } & \multicolumn{2}{|c|}{ Male gender } & \multicolumn{2}{c|}{ Female gender } & \multicolumn{2}{c||}{ Total } \\
\hline \hline Bicycle & 10 & $14.08 \%$ & 10 & $22.73 \%$ & 20 & $17.39 \%$ \\
\hline Falling & 47 & $66.20 \%$ & 26 & $59.09 \%$ & 73 & $63.48 \%$ \\
\hline Punches & 14 & $19.72 \%$ & 8 & $18.18 \%$ & 22 & $19.13 \%$ \\
\hline \hline \multicolumn{1}{|c||}{ Total } & 71 & $100.00 \%$ & 44 & $100.00 \%$ & 115 & $100.00 \%$ \\
\hline
\end{tabular}

Table 3. Types of injuries of periodontal soft tissues

\begin{tabular}{||l||c|c|c|c|c|c||}
\hline \multicolumn{1}{|c||}{ Type of soft tissue injury } & \multicolumn{2}{c|}{ Male gender } & \multicolumn{2}{c|}{ Female gender } & \multicolumn{2}{c||}{ Total } \\
\hline \hline Laceration & 18 & $25.35 \%$ & 13 & $29.55 \%$ & 31 & $26.96 \%$ \\
\hline Contusion & 11 & $15.49 \%$ & 14 & $31.82 \%{ }^{*}$ & 25 & $21.74 \%$ \\
\hline Abrasion & 7 & $9.86 \%$ & 1 & $2.27 \%$ & 8 & $6.96 \%$ \\
\hline Swelling & 7 & $9.86 \%$ & 4 & $9.09 \%$ & 11 & $9.57 \%$ \\
\hline
\end{tabular}

$* p<0.05$

Table 4. Type of primary teeth injury

\begin{tabular}{||l||c|c|c|c|c|c||}
\hline \hline \multirow{2}{*}{ Type of primary teeth injury } & \multicolumn{2}{|c|}{ Male gender } & \multicolumn{2}{c|}{ Female gender } & \multicolumn{2}{c||}{ Total } \\
\hline \hline Subluxation & 39 & $54.93 \%$ & 21 & $47.73 \%$ & 60 & $52.17 \%$ \\
\hline Intrusion & 18 & $25.35 \%$ & 10 & $22.73 \%$ & 28 & $24.35 \%$ \\
\hline Extrusion & 10 & $14.08 \%$ & 7 & $15.91 \%$ & 17 & $14.78 \%$ \\
\hline Lateral luxation & 11 & $15.49 \%$ & 10 & $22.73 \%$ & 21 & $18.26 \%$ \\
\hline Avulsion & 7 & $9.86 \%$ & 8 & $18.18 \%$ & 15 & $13.04 \%$ \\
\hline Fracture & 6 & $8.45 \%$ & 4 & $9.09 \%$ & 10 & $8.70 \%$ \\
\hline \hline
\end{tabular}


Table 5. Injuries to the hard dental tissue and the pulp

\begin{tabular}{|l|c|c|c|c|c|c||}
\hline \multicolumn{1}{|c|}{ Dg of primary teeth injury } & \multicolumn{2}{c|}{ Male gender } & \multicolumn{2}{c|}{ Female gender } & \multicolumn{2}{c||}{ Total } \\
\hline \hline Enamel fracture & 2 & $2.82 \%$ & 3 & $6.82 \%$ & 5 & $4.35 \%$ \\
\hline Uncomplicated crown fracture & 2 & $2.82 \%$ & 0 & $0.00 \%$ & 2 & $1.74 \%$ \\
\hline Complicated crown fracture & 3 & $4.23 \%$ & 1 & $2.27 \%$ & 4 & $3.48 \%$ \\
\hline
\end{tabular}

\section{Discussion}

Numerous studies worldwide have suggested that modern lifestyles lead to increasingly more common injuries to the orofacial region. Injuries to the primary teeth and adjacent soft tissue have got a prominent place among them $(4,8)$. This study analyzed a sample of children with injuries to the primary teeth and adjacent soft tissue who visited the Dentistry Clinic for that reason. However, we should bear in mind that the number of injured children is most probably higher, since the children with small-scale injuries probably have not visited any doctor at all. Moreover, primary teeth usually draw less attention than permanent teeth and consequences of injuries to the primary teeth are usually perceived as less serious. In view of the fact that many teeth injuries were managed outside the Dentistry Clinic in out-patient clinics and in privately owned clinics, it can be assumed that this study cannot be taken to account for the number of injuries in the studied period.

Numerous studies have shown that primary teeth injuries are more prevalent in boys (9-16). Our results were similar - $61.74 \%$ of the injured were male children. However, Carvalho et al., in 1998, have shown in their study that injuries to the primary teeth are more common in girls. This could be explained by the fact that boys and girls aged up to 5 years are equally exposed to the risk of injury, since their activities and games are similar to a point.

Analyzing the results for examinees in different age groups, it was established that injuries were rare in children under 1 year of age (only $0.87 \%$ ), which agreed with the available literature data (17). In some studies it has been found that the prevalence of primary teeth injuries in children is highest in the period from 3 to 5 years of age (2, 15). In our study, these injuries most commonly occurred at the age of 2 years (30.43\%). It is the period of onset of independent walking, making the risk of traumas rather high - although they start to walk independently, without support of others, their movement coordination is still inadequate.

This study showed that periodontal tissue injuries were much more frequent than injuries to hard dental tissues. Other authors have got similar results $(3,9,18)$. Subluxation was the most common injury. Many authors have also indicated subluxation as the most common injury of the primary dentition $(2,4,9,18)$. The root of the primary teeth is shorter, with usually incomplete growth or with already started resorption, the crown is short and chunky and it is harder to break it, so that injuries to the supporting dental tissues are more frequent. The reason for more common injuries to periodontal tissues in primary dentition is the number and distribution of periodontal fibers and greater elasticity of the alveolar bone.

Bearing in mind that injuries to the primary and permanent dentition occur in different places, with different mechanisms of injury, under the action of different forces and objects and that these differ among particular age groups, it can be said that the etiology of tooth injury is very complex and depend on a multitude of interactions of different factors and circumstances. Home is the predominant place where dental injuries occur (as high as $52.17 \%)$. Other authors have come to the similar results $(3,19-21)$. Male examinees were slightly more frequently injured at home. Children were rarely injured in kindergartens (3.48\%), in contrast to the data presented by Skaare and Jacobsen, who reported a high rate of injuries in kindergartens (2, 22). Injuries were the consequence of insufficiently developed motoric abilities of children of that age. Other authors have come to the similar results (9, 13, 18, 23, 24).

Falling was the most common cause of injury $(63.48 \%$ of cases) and slightly more in boys (66.20\%) compared to girls (59.09\%). There are certain differences among the studies as to the most common causes of dental traumas, although falling is still the predominant cause $(9,13,18-21,23)$.

The research of Eyuboglu et al. has shown that $50 \%$ of injuries to the primary teeth were associated with periodontal tissue injuries (25). The most common soft tissue injury was laceration (26.96\%). Since lacerations are associated with visible bleeding, the parents were thus scared the most and were highly motivated to visit dentists on that account. This did not exclude the possibility that other soft tissue injuries were present in even higher proportions, but they simply passed unnoticed due to their much less dramatic clinical picture, so that parents thought it was not necessary to visit their dentists.

Since injuries occur in children from their earliest age, they represent a very difficult and unpleasant experience for both the injured children and their parents. These injuries can disturb the functions of mastication, speech and communication, and disrupt cosmesis of a child in the period of its most intense physical and psychological growth and development, which further stresses the significance of these injuries. 


\section{Conclusion}

Based on the obtained results, a conclusion may be drawn that:

- dental injuries in the primary dentition are more common in boys;

- dental injuries in the primary dentition are most common in the age of about 2 years;

- periodontal injuries are much more common than injuries to the hard dental tissue;

- lacerations are the most common soft tissue injuries;

- falls are the most common cause of dental injury in pediatric populations.

In childhood, teeth injuries are mostly the consequence of falls and playing, being thus very difficult to prevent. Therefore, it is not uncommon that these injuries are the reason for the child's first visit to a dentist. These traumas do not represent just a disruption of physical tissue integrity - these are also psychological traumas for both the injured children and their parents. An adequate approach by the dentist is thus essential in circumstances such as these.

\section{Acknowledgment}

This study was supported by the Ministry of Education, Science and Technological Development of the Republic of Serbia (project number 43012). 


\section{References}

1. Andreasen JO, Andreasen FM. Injuries to developing teeth. Textbook and color atlas of traumatic injuries to the teeth. Copenhagen: Munksgaard;1994a. p. 457494.

2. Skaare $A B$, Jacobsen I. Primary tooth injuries in Norwegian children (1-8 years). Dent Traumatol 2005;21(6):315-319. [CrossRef] [PubMed]

3. de Paula Barros JN, de Araújo TAA, Soares TRC, Lenzi MM, de Andrade Risso P, Fidalgo TKDS, et al. Profiles of Trauma in Primary and Permanent Teeth of Children and Adolescents. J Clin Pediatr Dent. 2019; 43(1):5-10. [CrossRef] [PubMed]

4. Malmgren $B$, Andreasen JO, Flores MT, Robertson A, DiAngelis AJ, Andersson $L$, et al. Guidelines for the Management of Traumatic Dental Injuries: 3. Injuries in the Primary Dentition. Pediatr Dent. 2017;39(6): 420-28. [CrossRef] [PubMed]

5. Hecova $H$, Tzigkounakis V, Merglova V, Netolitcky J. A retrospective study of 889 injured permanent teeth. Dent Traumatol 2010;26:466-475. [CrossRef] [PubMed]

6. Lygidakis NA, Marinou D, Katsaris N. Analysis of dental emergencies presenting to a community paediatric dentistry centre. Int J Paediatr Dent 1998;8(3):181190. [CrossRef] [PubMed]

7. Andreasen JO, Andreasen FM. Classification, etiology and epidemiology. Textbook and color atlas of traumatic injuries to the teeth. $\mathrm{p}$ 151-180. Copenhagen: Munksgaard; 1994b.

8. Mendoza-Mendoza A, Iglesias-Linares A, Yanez-Vico RM, AbalosLabruzzi C. Prevalence and complications of trauma to the primary dentition in a subpopulation of Spanish children in southern Europe. Dent Traumatol 2015;31:144-9. [CrossRef] [PubMed]

9. Avşar A, Topaloglu B. Traumatic tooth injuries to primary teeth of children aged 0-3 years (Turkey). Dent Traumatol 2009;25(3):323-7.

[CrossRef] [PubMed]

10. Avşar A, Topaloglu B Orofacial and dental trauma of young children in Dunedin, New Zealand. Dent Traumatol 2011;27(3):199-202. [CrossRef] [PubMed]

11. Wendt FP, Torriani DD, Assuncao MC, Romano AR, Menezes Bonow ML, Terra da Costa $C$, et al. Traumatic dental injuries in primary dentition: epidemiological study among preschool children in South Brazil. Dent Traumatol 2010 26(2):168-173. [CrossRef] [PubMed]

12. Robson $F$, Ramos Jorge $M L$, Bendo $C B$, Vale $M P$, Paiva SM, Pordeus IA. Prevalence and determining factors of traumatic injuries to primary teeth in preschool children. Dent Traumatol 2009;25(1):118-22. [CrossRef] [PubMed]

13. Choi SC, Park JH, Pae A, Kim JR. Retrospective study on traumatic dental injuries in preschool children at Kyung Hee Dental Hospital, Seoul, South Korea. Dent Traumatol 2010;26(1):70-5. [CrossRef] [PubMed]
14. Abanto J, Paiva SM, Raggio DP, Celiberty P, Aldrigui JM, Bonecker M. The impact of dental caries and trauma in children on family quality of life. Community Dent Oral Epidemiol 2012;40:323-31. [CrossRef] [PubMed]

15. Cully JL, Zeeb K, Sahay RD, Gosnell E, Morris H, Thikkurissy S. Prevalence of Primary Teeth Injuries Presenting to a Pediatric Emergency Department. Pediatr Dent 2019;41(2):136-39. [PubMed]

16. Assunção LR, Ferelle $A$, Iwakura $M L$, Nascimento LS, Cunha RF. Luxation injuries in primary teeth: a retrospective study in children assisted at an emergency service. Braz Oral Res 2011;25(2):150-6. [CrossRef] [PubMed]

17. Andreasen JO, Andreasen FM, Andersson L. Textbook and Color Atlas of Traumatic Injuries to the Teeth. 4th ed. Copenhagen: Blackwell Munksgaard; 2007.

18. de Amorim Lde F, da Costa LR, Estrela C. Retrospective study of traumatic dental injuries in primary teeth in a Brazilian specialized pediatric practice. Dent Traumatol 2011;27(5):368-73. [CrossRef] [PubMed]

19. ElKarmi RF, Hamdan MA, Rajab LD, Abu-Ghazaleh SB, Sonbol HN. Prevalence of traumatic dental injuries and associated factors among preschool children in Amman, Jordan. Dent Traumatol. 2015;31(6):487-92. [CrossRef] [PubMed]

20. Norton E, O'Connel AC. Traumatic dental injuries and their association with malocclusion in the primary dentition of Irish children. Dent Traumatol 2012; 28:81-6. [CrossRef] [PubMed]

21. Lam R. Epidemiology and outcomes of traumatic dental injuries: a review of the literature. Aust Dent J. 2016;61 (Suppl) 1:4-20. [CrossRef] [PubMed]

22. Glendor $U$, Jonsson $D$, Halling $A$, Lindqvist $K$. Direct and indirect costs of dentaltrauma in Sweden: a 2year prospective study of children and adolescents. Community Dent Oral Epidemiol 2001;29:150-60. [CrossRef] [PubMed]

23. Jorge KO, Moyses SJ, Ferreira e Ferreira E, RamosJorge ML, Pereira de Araujo Zarzar PM. Prevalence and factors associated to dental trauma in infants 1-3 years of age. Dent Traumatol 2009;25(2):185-9. [CrossRef] [PubMed]

24. Antunes LAA, Antunes LS, Luiz RR, Leao ATT, Maia LC. Assessing the responsiveness of the Brazilian FIS to treatment for traumatic dental injury. Community Dent Oral Epidemiol 2013;41:551-7. [CrossRef] [PubMed]

25. Eyuboglu O, Yilmaz Y, Zehir C, Sahin H. A 6-year investigation into types of dental trauma treated in a paediatric dentistry clinic in Eastern Anatolia region, Turkey. Dent Traumatol 2009;25(1):110-4. [CrossRef] [PubMed] 


\title{
POVREDE MLEČNIH ZUBA I MEKIH TKIVA KOD DECE U NIŠU (SRBIJA)
}

\author{
Ana Igić1 , Branislava Stojković2,3, Aleksandar Mitić2,4, Aleksandar Acović5, \\ Kosta Todorović2,6, Ana Todorovićz ${ }^{2,7}$, Dušan Sokolović2,8, Marija Igić ${ }^{2}$ \\ ${ }^{1}$ Univerzitet u Nišu, Medicinski fakultet, student doktorskih studija, Niš, Srbija \\ ${ }^{2}$ Univerzitet u Nišu, Medicinski fakultet, Niš, Srbija \\ ${ }^{3}$ Klinika za stomatologiju, Odeljenje za preventivnu i dečiju stomatologiju, Niš, Srbija \\ ${ }^{4}$ Klinika za stomatologiju, Odeljenje za endodonciju, Niš, Srbija \\ 5Univerzitet u Kragujevcu, Fakultet medicinskih nauka, Odeljenje za stomatologiju, Kragujevac, Srbija \\ ${ }^{6}$ Klinika za stomatologiju, Odeljenje za oralnu hirurgiju, Niš, Srbija \\ ${ }^{7}$ Klinika za stomatologiju, Odeljenje za ortodonciju, Niš, Srbija \\ ${ }^{8}$ Univerzitet u Nišu, Medicinski fakultet, Katedra za biohemiju, Niš, Srbija
}

Kontakt: Ana igić

Bulevar dr Zorana Đnđića 81, 18000 Niš, Srbija

E-mail: igic.ana77@gmail.com

Cilj rada bio je da se izvrši analiza povreda mlečnih zuba i okolnih mekih tkiva, u odnosu na pol i uzrast povređenih ispitanika, vrstu povrede i mesto i način povređivanja. Ispitivanjem je obuhvaćeno 115 dece (71 dečak i 44 devojčice), koja su zbrinuta na Klinici za stomatologiju Medicinskog fakulteta Univerziteta u Nišu, u periodu od 2009. do 2019. godine. Podaci o vrsti povrede i mestu i načinu povređivanja dobijeni su iz traumatoloških kartona bolesnika, uzrasta od 1 godine do 5 godina. Analizom je utvrđeno da je statistički značajno više $(p<0,05)$ bilo povređenih dečaka $(61,74 \%)$ nego devojčica $(38,26 \%)$. Najčešća povreda mlečnih zuba je subluksacija, koja je prisutna kod $60(52,17 \%)$ dece i statistički je značajno zastupljenija $u$ odnosu na ostale povrede $(p<0,001)$. Od povreda okolnih mekih tkiva, laceracija je statistički značajno zastupljenija od ostalih povreda mekih tkiva $(p<0,001)$. Deca su se najčešće povređivala u kući $(52,17 \%)$, a najređe u vrtiću $(3,48 \%)$. Najčešći uzrok povrede je pad $(63,48 \%)$. Na osnovu dobijenih rezultata može se zaključiti da su se dečaci više povređivali od devojčica i da je najčešći uzrok povrede pad. Povrede su se najčešće događale u uzrastu oko 2 . godine života. Od svih povreda najzastupljenija je bila subluksacija, a deca su se najćešće povređivala u kući.

Acta Medica Medianae 2021;60(1):56-62.

Ključne reči: mlečni zubi, povrede, subluksacija, laceracija 